\title{
Immunoglobulin synthesis by neoplastic cells: models of a clonal transition from IgM to IgG synthesis
}

\author{
J GORDON AND JL SMITH
}

From the Regional Immunology Service, Tenovus, Southampton, UK

SUMMARY Tumour populations from two B cell neoplasms were investigated for their capacity to synthesise immunoglobulin in vitro. Neoplastic cells from a patient with chronic lymphocytic leukaemia and an IgG $\lambda$ paraproteinaemia co-expressed surface $\operatorname{IgG} \lambda$ and $\operatorname{IgM} \lambda$ and synthesised both $\operatorname{IgG} \lambda$ and $\operatorname{IgM} \lambda$ in short-term culture. In the second patient with non-Hodgkin's lymphoma, the neoplastic cells expressed surface $\operatorname{IgM} \lambda$ but synthesised both $\operatorname{IgM} \lambda$ and $\operatorname{IgG} \lambda$ in vitro. The findings are discussed in terms of a model for the clonal switch from IgM to IgG synthesis.

Small resting B-lymphocytes synthesise immunoglobulin molecules which are displayed at the surface membrane to serve as receptor for antigen. ${ }^{1}$ Encounter with the appropriate antigen may result in clonal proliferation with differentiation to immunoglobulin secreting plasma cells. IgM is thought to serve as the prime antigen receptor, and it has been suggested that all immunoglobulin secreting clones arise from precursor cells bearing this isotype. ${ }^{2-6}$ Thus, while clonal stability is preserved by maintaining the expression of one set of variable region genes during differentiation, adjunctive functional properties of immunoglobulin may be altered by a switch in the phenotypic expression of the heavy chain constant region genes. Such a switch from IgM to IgG synthesis has been well documented in vitro, and cells simultaneously expressing both classes have been described. ${ }^{7-10}$

Many B-cell neoplasms appear to represent malignant clones frozen at a particular stage in B-cell differentiation. ${ }^{1112}$ The capacity of such neoplastic populations to synthesise immunoglobulin in vitro and their associative patterns of immunoglobulin expression have been related to that of normal morphological counterparts for both murine and human tumours. ${ }^{13-16}$ In this report we describe a case of chronic lymphocytic leukaemia (CLL) and a case of non-Hodgkin's lymphoma where the patterns of immunoglobulin expression and synthesis appeared to reflect a stage in normal B-cell

Received for publication 20 November 1979 development corresponding to a clonal transition in the switch from IgM to IgG synthesis.

\section{Material and methods}

PATIENTS AND CELL PREPARATION

Two patients were studied. RIT is a 59-year-old man, who presented with generalised lymphadenopathy, enlarged spleen, and a pleural effusion. A representative sample of a supraclavicular lymph node biopsy for histology was studied. At the time of study his serum immunoglobulins were IgG 16.4 , $\operatorname{IgA} 1 \cdot 0$, and $\operatorname{IgM} 0.2 \mathrm{~g} / 1$. Normal ranges for this laboratory are IgG 7.2-13.0, IgA 1.0-3.6, IgM 0.5$1.5 \mathrm{~g} / \mathrm{l}$. No serum immunoglobulin abnormality was detected by electrophoretic strip or immunoelectrophoretic analyses. No Bence Jones protein was detected in a $\times 200$ concentrated 24-hour urine specimen by electrophoretic strip analysis.

The second patient (HIB) presented with chronic lymphocytic leukaemia. At the time of study this 70-year-old man's peripheral lymphocyte count was $44 \times 10^{9} / 1$. His serum immunoglobulin levels were $\operatorname{IgG} 25 \cdot 2$, IgA $1 \cdot 7$, and $\operatorname{IgM} 0.9 \mathrm{~g} / \mathrm{l}$ with an $\operatorname{IgG} \lambda$ paraprotein in the slow $\gamma$ region of the electrophoretic strip which accounted for approximately $80 \%$ of the total immunoglobulins. No Bence Jones protein was detected in a $\times 200$ concentrated 24 -hour urine specimen. Cells were prepared from heparinised peripheral blood (HIB) and from lymph node biopsy tissue (RIT) finely minced and teased in cold HEPES buffered Eagle's minimal essential mepium 
(HEPES-MEM, Biocult Laboratories, Paisley, Scotland). Cell preparations for study were obtained after Ficoll-Triosil separation. Cells collected at the interface were washed three times, and the final pellet was resuspended at $5 \times 10^{6} / \mathrm{ml}$ in culture medium for analysis.

\section{CELL RECEPTORS}

Rosette tests for the identification of cells with receptors for $\mathrm{Fc} \gamma$, the $\mathrm{C} 3$ component of complement, and for sheep erythrocytes (E) have been described fully elsewhere. ${ }^{17-19}$ Cell suspensions were stained with fluorescein-conjugated antisera to immunoglobulin heavy and light chains. ${ }^{20}$ Cell smears fixed in methanol and washed in saline were also stained with these antisera by the direct method. Controls were included in all experiments. The fluorescein-labelled preparations were examined using a Leitz Orthoplan microscope fitted with an HB 200 mercury vapour Ploem illuminator.

\section{IMMUNOGLOBULIN SYNTHESIS}

The biosynthetic labelling techniques and the subsequent characterisation and quantification of labelled immunoglobulin have been described in detail elsewhere. ${ }^{16}$ Briefly, cells at $5 \times 10^{6}$ per $\mathrm{ml}$ were incubated in leucine-free medium containing ${ }^{3} \mathrm{H}$-leucine at $25 \mu \mathrm{Ci} / \mathrm{ml}$ for 18 hours at $37^{\circ} \mathrm{C}$. Cells were separated from the supernatants by centrifugation $(150 \mathrm{~g}, 15 \mathrm{~min})$ and lysed with phosphatebuffered saline (PBS) containing detergent NP40 and proteolytic inhibitors. Both the cell lysates and supernatants were spun at $35000 \mathrm{~g}$ to remove cell debris and dialysed exhaustively against PBS. The radioactivity incorporated in all macromolecules was determined by precipitation with $10 \%$ trichloroacetic acid (TCA). Labelled immunoglobulin was precipitated using a sandwich technique with sheep antiserum specific for human immunoglobulin as the first antibody and rabbit antiserum with activity to sheep immunoglobulin as the second antibody. Normal sheep serum was used as the first antibody in control precipitations. These immunoglobulin precipitates were washed three times with cold PBS before counting or preparation for gel analysis. Reduced and alkylated immunoglobulin precipitates were analysed on $9.5 \mathrm{~cm}$ long $7.5 \%$ SDS-polyacrylamide gel electrophoresis with radioactive myeloma immunoglobulin markers. The labelled immunoglobulin light chain class was assessed by precipitation with $\kappa$ - or $\lambda$-specific antiserum. These antisera were prepared from sheep immunised with pooled $\kappa$ - or $\lambda$-Bence Jones protein and absorbed on Sepharose 4B (Pharmacia, Sweden) coupled to either $\kappa$ - or $\lambda$-Bence Jones protein to remove crossreactivity. The specificity of these antisera has been described. ${ }^{21}$ Antiserum specific for heavy chains in the immunoprecipitation test was not available at the time of this study.

\section{Results}

Final preparations were found to contain greater than $94 \%$ lymphoid cells, the remaining cells being either monocytes or granulocytes. In both preparations, strong staining for surface immunoglobulin (SIg) was observed on a majority of cells (Table 1). In the case of RIT, SIg was characterised as IgM $\lambda$. All positive cells in preparation HIB stained strongly for IgG and $\lambda$ chains, while approximately half exhibited additional weak staining for IgM (Table 1). No cells staining for cytoplasmic immunoglobulin were detected in either preparation among approximately 10000 cells scanned. The percentages of cells in each preparation forming spontaneous sheep erythrocyte rosettes or expressing receptors for $\mathrm{Fc} \gamma$ or $\mathrm{C} 3$ are shown in Table 1.

When cultured in the presence of radioactive leucine, both cell preparations synthesised and secreted detectable quantities of labelled immunoglobulin (Table 2); immunoglobulin accounted for $0.9 \%$ of all labelled protein in HIB culture and $4.8 \%$ in RIT culture. In both cultures, $>90 \%$ of the labelled supernatant immunoglobulin was pre-

Table 1 Cell surface marker data

\begin{tabular}{|c|c|c|c|c|c|c|c|c|c|c|c|}
\hline \multirow[t]{3}{*}{ Patient } & \multirow[t]{3}{*}{ Preparation } & \multicolumn{10}{|c|}{ Surface marker } \\
\hline & & \multirow[t]{2}{*}{$E \dagger$} & \multirow[t]{2}{*}{$F c \gamma$} & \multirow[t]{2}{*}{$C 3$} & \multirow{2}{*}{$\begin{array}{l}{ }^{*} S / g \\
\text { poly }\end{array}$} & \multicolumn{6}{|c|}{ *SIg class } \\
\hline & & & & & & $G$ & $A$ & $M$ & $D$ & $\kappa$ & $\lambda$ \\
\hline $\begin{array}{l}\text { RIT }_{+}^{+} \\
\text {HIB } \$\end{array}$ & $\begin{array}{l}\text { Lymph node } \\
\text { Peripheral blood }\end{array}$ & $\begin{array}{r}28 \\
7\end{array}$ & $\begin{array}{l}18 \\
96\end{array}$ & $\begin{array}{l}51 \\
22\end{array}$ & $\begin{array}{l}65 \\
93\end{array}$ & $\begin{array}{r}2 \\
94\end{array}$ & $\begin{array}{l}0 \\
0\end{array}$ & $\begin{array}{l}67 \\
43\end{array}$ & $\begin{array}{l}0 \\
0\end{array}$ & $\begin{array}{l}2 \\
0\end{array}$ & $\begin{array}{l}64 \\
89\end{array}$ \\
\hline
\end{tabular}

*After incubation for 1 hour at $37^{\circ} \mathrm{C}$.

†Spontaneous sheep erythrocyte rosettes.

‡Examination of RIT peripheral blood and bone marrow cells revealed no evidence for lymphoma spillover.

$\S$ Examination of HIB bone marrow cells revealed essentially the same profile as that of peripheral blood. 
Table 2 Biosynthetic studies

\begin{tabular}{|c|c|c|c|c|c|c|}
\hline \multirow[t]{3}{*}{ Patient } & \multicolumn{2}{|l|}{ Lysate } & \multicolumn{4}{|l|}{ Supernatant } \\
\hline & \multirow[t]{2}{*}{$T C A$ counts* } & \multirow{2}{*}{$\begin{array}{l}\text { Ig as } \% \\
\text { total protein }\end{array}$} & \multirow[t]{2}{*}{$T C A$ counts } & \multirow{2}{*}{$\begin{array}{l}\text { Ig as } \% \\
\text { total protein }\end{array}$} & \multicolumn{2}{|c|}{$\%$ Ig ppted with: } \\
\hline & & & & & anti- $\lambda$ & anti- $\kappa$ \\
\hline $\begin{array}{l}\text { HIB } \\
\text { RIT }\end{array}$ & $\begin{array}{l}1384200 \\
1631480\end{array}$ & $\begin{array}{l}0.4 \\
1.6\end{array}$ & $\begin{array}{l}177580 \\
276340\end{array}$ & $\begin{array}{l}0.5 \\
3 \cdot 2\end{array}$ & $\begin{array}{r}95 \\
100\end{array}$ & $\begin{array}{l}5 \\
0\end{array}$ \\
\hline
\end{tabular}

${ }^{*} \mathrm{cpm}$ per $10^{6}$ cells.

cipitated with antiserum specific for $\lambda$ light chain; anti- $\kappa$ precipitated only minimal counts from both culture supernatants (Table 2 ).

Gel profiles of the reduced and alkylated labelled immunoglobulin from HIB and RIT culture supernatants are illustrated in the Figure. Peaks were identified in the $\mu, \gamma$, and light chain positions for both cultures; light chain was present in molar excess of heavy chain in HIB culture. An additional peak with a mobility intermediate between that of $\gamma$ and light chain was present in the control and specific precipitations of HIB supernatant and both HIB and RIT lysates. The proportion of supernatant and lysate immunoglobulin (not including free light chain) characterised as IgM or IgG is given in Table 3. The relative amount of labelled immunoglobulin detectable in the supernatant compared to cell lysate gives the secretory index (Table 3 ).

\section{Discussion}

In many cases, B-cell neoplasms appear to represent malignant clones arrested at a particular stage in the maturation pathway of small resting B-lymphocytes to immunoglobulin-exporting plasma cells. ${ }^{11} 12$ It has been suggested that patterns of immunoglobulin expression associated with such neoplastic clones may reflect those of normal morphological counterparts. ${ }^{14}{ }^{15} \mathrm{In}$ an attempt to extend these concepts, we have been investigating the capacity of tumour B-cell populations to synthesise and secrete immunoglobulin in vitro.1621 The synthesis patterns of approximately 50 cases of leukaemia and lymphoma now studied suggest that, with caution, extrapolation of the findings to normal analogues may be validthis is in agreement with the model originally proposed by Andersson et al., ${ }^{13}$ working with murine

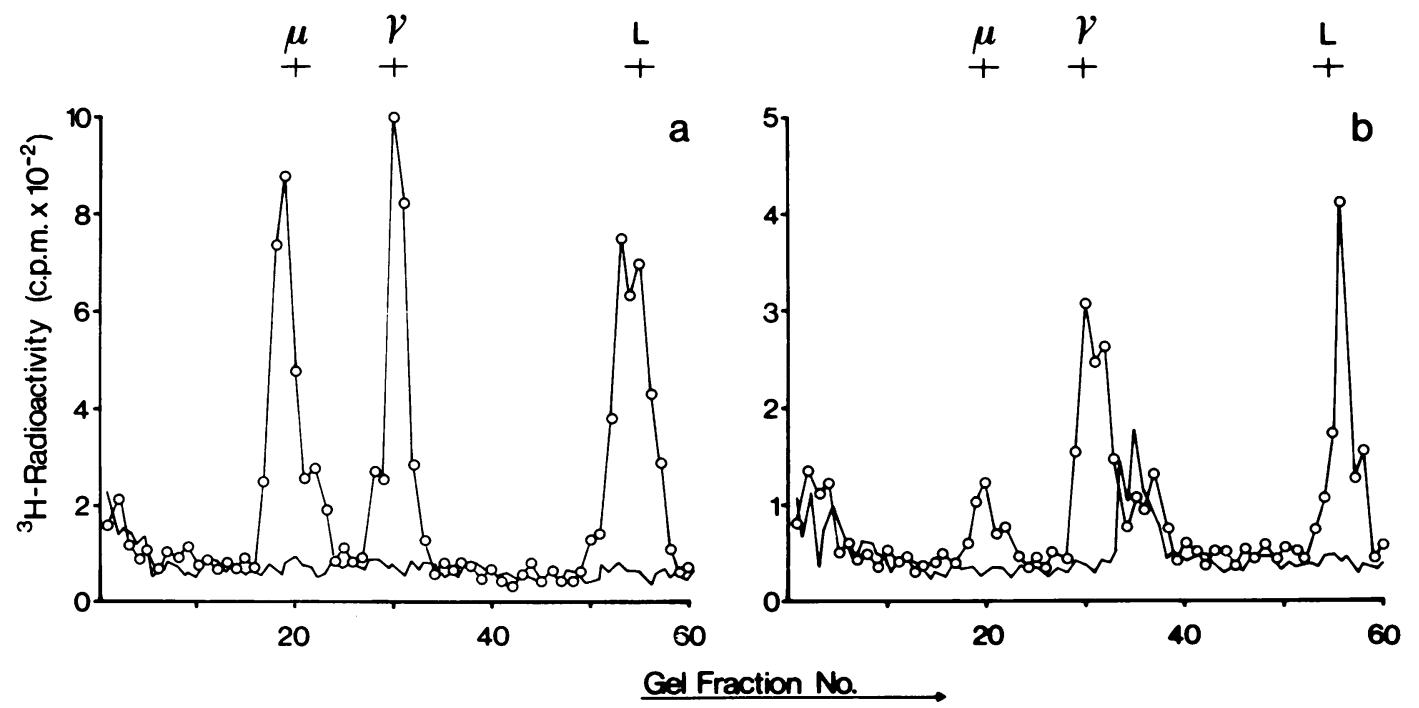

$7.5 \%$ Polyacrylamide gel electrophoresis of reduced and alkylated immunoglobulin precipitated from culture supernatants of (a) RIT, (b) HIB. The positions of myeloma $\mu, \gamma$, and light chain (L) markers are shown: $\bigcirc-\bigcirc$ specific precipitation; control precipitation. 
Table 3 IgM and IgG synthesis

\begin{tabular}{|c|c|c|c|c|c|c|}
\hline \multirow[t]{2}{*}{ Patient } & \multicolumn{3}{|l|}{$\operatorname{Ig} M$} & \multicolumn{3}{|l|}{$I g G$} \\
\hline & $\%$ Lysate Ig* & $\%$ Supernatant Ig & Secretory indext & $\%$ Lysate Ig & $\%$ Supernatant Ig & Secretory index \\
\hline $\begin{array}{l}\text { HIB } \\
\text { RIT }\end{array}$ & $\begin{array}{l}28 \\
76\end{array}$ & $\begin{array}{l}10 \\
48\end{array}$ & $\begin{array}{l}0.4 \\
1.3\end{array}$ & $\begin{array}{l}72 \\
24\end{array}$ & $\begin{array}{l}90 \\
52\end{array}$ & $\begin{array}{l}1 \cdot 5 \\
4 \cdot 3\end{array}$ \\
\hline
\end{tabular}

* Determined from relative size of $\mu$ and $\gamma$ peaks on SDS gels.

†Determined from gel analysis and immunoprecipitation (see Table 2) as ratio of supernatant to lysate immunoglobulin.

lymphomas. The two cases reported in this paper were exceptional among those so far studied by us in that there was evidence for the simultaneous synthesis of IgM and IgG by the neoplastic clones. While IgG may often be detectable on IgM bearing cells, its presence is usually artefactual, ${ }^{22}$ and true double expression of these isotypes appears to be rare. ${ }^{823}$ It has been suggested that cells exhibiting this characteristic reflect a transition stage in the clonal switch from IgM to IgG synthesis. ${ }^{24}$

For both cases described in this paper, identity of synthesised immunoglobulin with the neoplastic clone was strongly suggested by the sharing of a single light chain class for labelled and cell surface membrane immunoglobulin. In both cultures, less than $5 \%$ of the total immunoglobulin was associated with $\kappa$ light chain. Labelled immunoglobulin heavy chain was characterised from its mobility on SDSpolyacrylamide gels with reference to heavy chain markers. While it is possible that proteolysis could have occurred during cell culture, giving rise to artefactual peaks, control experiments in which 125I-labelled IgM and IgG were present throughout an 18-hour incubation did not reveal observable breakdown of these proteins. Furthermore, in our experience, where degradation does occur, the breakdown products appear as heterogeneous fragments on gel analysis. For both HIB and RIT, labelled protein specifically precipitated by anti-immunoglobulin revealed discrete peaks with mobilities on SDS-gels coincident with the appropriate marker proteins.

The presence of monotypic labelled IgG and IgM in the culture of HIB cells was consistent with the dual expression of these isotypes at the tumour cell surface membrane. Neither isotype was removed on incubating the cells at $37^{\circ} \mathrm{C}$, a procedure shown to dissociate extrinsically bound immunoglobulin. ${ }^{22}$ This patient also presented with an IgG $\lambda$ paraproteinaemia, and IgG $\lambda$ was the major immunoglobulin class detected in the supernatant of the neoplastic peripheral blood cell culture. Our inability to detect IgG in the patient's peripheral blood or bone marrow cells by immunofluorescent criteria is not surprising, considering the low level of biosynthetic labelling for intracellular immuno- globulin that was detected. In two cases of myeloma studied by us, the neoplastic plasma cells synthesised approximately 100 -fold more immunoglobulin than was seen with HIB cells (unpublished observation). While a large tumour mass of CLL cells secreting relatively small amounts of monoclonal immunoglobulin may have accounted for the serum paraprotein detected in this patient we cannot exclude the possibility that more mature cells, residing in some compartment other than peripheral blood or bone marrow, could have been responsible.

The ability of RIT cells to synthesise simultaneously IgM and IgG was of particular interest as IgM only was detected at the neoplastic cell surface. While only $67 \%$ of cultured cells were identificd as neoplastic, the majority of the remainder had the characteristics of T-cells. No plasma cells were detected, and it is unlikely that such high levels of synthesis observed for IgG could have been associated with any normal B-cell elements that may have been present. Furthermore, the monotypic light chain specificity of the labelled immunoglobulin provides good evidence for a neoplastic origin. At the termination of the culture the majority of the labelled IgG was present in the supernatant, suggesting that this protein was being synthesised primarily for export. Immunoglobulin secretion in the absence of intracellular staining and a detectable surface phase has been previously described by us for free light chain from some surface immunoglobulin negative cases of CLL. ${ }^{16}$

The rate at which immunoglobulin was synthesised and secreted differed considerably between the two cases studied. In common with other cases of CLL, HIB cells synthesised and secreted immunoglobulin at a low rate. ${ }^{16}$ In contrast, RIT lymphoma cells synthesised relatively large amounts of immunoglobulin with a rapid turnover into the extracellular environment; these differences, coupled with the contrasting patterns of membrane immunoglobulin expression, suggest that HIB and RIT neoplastic clones may reflect maturation arrests in different compartments of B-cell development, possibly corresponding to a transition stage in the IgM to IgG switch occurring during a primary and a secondary response respectively. 
We thank the Leukaemia Research Fund, the Wessex Oncology Fund, and the Wessex Regional Health Authority for financial support.

\section{References}

${ }^{1}$ Raff MC, Sternberg M, Taylor RB. Immunoglobulin determinants on the surface of mouse lymphoid cells. Nature 1970;225:553-4.

${ }^{2}$ Kincade PW, Lawton AR, Bockman DE, Cooper MD. Suppression of immunoglobulin $G$ synthesis as a result of synthesis antibody-mediated suppression of immunoglobulin M in chickens. Proc Natl Acad Sci 1970;67:1918-25.

${ }^{3}$ Lawton AR III, Asofsky R, Hylton MB, Cooper MD. Suppression of immunoglobulin class synthesis in mice. I. Effects of treatment with antibody to $\mu$-chain. $J$ Exp Med 1972;135:277-97.

${ }^{4}$ Pierce CW, Solliday SM, Asofsky R. Immune responses in vitro. V. Suppression of $\gamma \mathrm{M}, \gamma \mathrm{G}$ and $\gamma \mathrm{A}$ plaque forming cell responses in cultures of primed mouse spleen cells by class-specific antibody to mouse immunoglobulins. $J$ Exp Med 1972;135: 698-710.

${ }^{5}$ Kearney JF, Cooper MD, Lawton AR. B lymphocyte differentiation induced by lipopolysaccharide. III. Suppression of $\mathbf{B}$ cell maturation by anti-mouse immunoglobulin antibodies. $J$ Immunol 1976a; 116:1664-8.

6 Abney ER, Cooper MD, Kearney JF, Lawton AR, Parkhouse RME. Sequential expression of immunoglobulin on developing mouse B lymphocytes: A systematic survey that suggests a model for the generation of immunoglobulin isotype diversity. $J$ Immunol 1978;120:2041-9.

${ }^{7}$ Kearney JF, Cooper MD, Lawton AR. B cell differentiation induced by lipopolysaccharide. IV. Development of immunoglobulin class restriction in precursors of IgG synthesizing cells. J Immunol 1976b; 117:1567-72.

${ }^{8}$ Pernis B, Forni L, Luzzati AL. Synthesis of multiple immunoglobulin classes by single lymphocytes. Cold Spring Harbor Symp Quant Biol 1977;41, pt. 1: 175-83.

${ }^{9}$ Kearney JF, Lawton AR, Cooper MD. Multiple immunoglobulin heavy chain expression by LPS stimulated murine B lymphocytes. In: Sercarz E, Herzenberg LA, Fox CF, eds. ICN-UCLA Symposia on Molecular and Cellular Biology, Vol VI Immune System: Genetics and Regulation. New York: Academic Press, 1977:313-20.

${ }^{10}$ Wabl MR, Forni L, Loor F. Switch in immunoglobulin class production observed in single clones of committed lymphocytes, Science 1978;199:1078-9.
${ }^{11}$ Salmon SE, Seligmann M. B-cell neoplasia in man. Lancet 1974;2:1230-3.

12 Lukes RJ, Collins RD. New approaches to the classification of the lymphomata. Brit $J$ Cancer 1975;31:Suppl.2:1-28.

${ }^{13}$ Andersson J, Buxbaum J, Citronbaum $\mathrm{R}$ et al. IgM-producing tumors in the BALB/c mouse: a model for B-cell maturation. $J$ Exp Med 1974;140: 742-63.

${ }^{14}$ Leech JH, Glick AD, Waldron JA, Flexner JM, Horn RG, Collins RD. Malignant lymphomas of follicular center cell origin in man. I. Immunologic studies. $J$ Natl Cancer Inst 1975;54:11-21.

15 Payne SV, Smith JL, Jones DB, Wright DH. Lymphocyte markers in non-Hodgkin's lymphomas. Brit $J$ Cancer 1977;36:57-64.

${ }^{16}$ Gordon J, Howlett AR, Smith JL. Free light chain synthesis by neoplastic cells in chronic lymphocytic leukaemia and non-Hodgkin's lymphoma. Immunology 1978;34:397-404.

${ }^{17}$ Hallberg T, Haegert D, Clein GP, Coombs RRA, Feinstein A, Gurner BW. Observations on the mixed antiglobulin reaction as a test for immunoglobulin-bearing lymphocytes in normal persons and in patients with chronic lymphatic leukaemia. $J$ Immunol Meth 1974;4:317-32.

${ }^{18}$ Smith JL, Haegert D. B- and T-lymphocyte markers on transformed lymphocytes from mitogen-stimulated cultures of normal and CLL lymphocytes and on tonsil blasts. Clin Exp Immunol 1974;17:547-60.

19 Payne SV, Jones DB, Haegert DG, Smith JL, Wright DH. T and B lymphocytes and Reed-Sternberg cells in Hodgkin's disease lymph nodes and spleens. Clin Exp Immunol 1976;24:280-6.

${ }^{20}$ Gordon J, Hough D, Karpas A, Smith J L. Immunoglobulin expression and synthesis by human haemic cell lines. Immunology 1977;32:559-65.

${ }^{21}$ Gordon J, Smith JL. Free immunoglobulin light chain synthesis by neoplastic cells in leukaemic reticuloendotheliosis. Clin Exp Immunol 1978;31:244-50.

${ }^{22}$ Lobo PI, Westervelt FB, Horwitz DA. Identification of two populations of immunoglobulin-bearing lymphocytes in man. J Immunol 1975;114:116-9.

${ }^{23}$ Preud'homme JL, Brouet JC, Seligmann M. Menibranebound IgD on human lymphoid cells, with special reference to immunodeficiency and immunoproliferative disease. Immunol Rev 1977;37:127-51.

${ }^{24}$ Rudders RA, Howard JP. Pathways of human B lymphocyte differentiation: A clonal transition between IgM and IgG synthesis in leukaemic B lymphocytes. J Immunol 1977;119:283-6.

Requests for reprints to: Dr J Gordon, Tenovus Research Laboratory, Southampton General Hospital, Southampton SO9 4XY, UK. 